\title{
Biofilm formation and acyl homoserine lactone production in Hafnia alvei isolated from raw milk
}

\author{
ELISETH SOUZA VIANA ${ }^{1}$, MARIA EMILENE MARTINO CAMPOS ${ }^{2}$, \\ ADRIANA REIS PONCE ${ }^{2}$, HILÁRIO CUQUETTO MANTOVANI ${ }^{2}$ \\ and MARIA CRISTINA DANTAS VANETTI ${ }^{2}$
}

\footnotetext{
${ }^{1}$ Research National Center of Cassava and Tropical Fruits, Brazilian Company of Agricultural Research, Cruz das Almas, BA, Brazil.

${ }^{2}$ Department of Microbiology, Federal University of Viçosa, MG, Brazil.
}

\begin{abstract}
The objective of this study was to detect the presence of acyl homoserine lactones (AHLs), signal molecules of the quorum sensing system in biofilm formed by Hafnia alvei strains. It also evaluated the effect of synthetic quorum sensing inhibitors in biofilm formation. AHLs were assayed using well diffusion techniques, thin layer chromatography (TLC) and detection directly in biofilm with biomonitors. The extracts obtained from planktonic and sessile cell of $H$. alvei induced at least two of three monitor strains evaluated. The presence of AHLs with up to six carbon atoms was confirmed by TLC. Biofilm formation by $H$. alvei was inhibited by furanone, as demonstrated by 96 -well assay of crystal violet in microtitre plates and by scanning electron microscopy. The H. alvei 071 hall mutant was deficient in biofilm formation. All these results showed that the quorum sensing system is probably involved in the regulation of biofilm formation by $H$. alvei.
\end{abstract}

Key terms: acyl homoserines lactones, biofilm, furanones, quorum sensing

\section{INTRODUCTION}

Hafnia alvei include a heterogeneous cluster of gram-negative, motile, flagellated rod shaped bacteria that belongs to the family of Enterobacteriacea (Sakazaki and Tamura, 1992). This bacterium is recognized as an opportunistic pathogen, found in many nosocomial infections, such as wounds and enteric, urinary and respiratory tract disorders (Katzenellenbogen et al., 2001). It is isolated from dairy (Desmasures, 1995; Pinto, 2004; Kagkli et al., 2007) meat and fish products (Lindberg et al., 1998; Gram et al., 1999; Bruhn et al., 2004) as a common bacterial food contaminant. $H$. alvei has the potential to form biofilms (Jack et al., 1992; Vivas et al., 2008) that confer considerable advantages to it, including the ability to resist challenges from the environment, the presence of antibiotics and sanitizers, and host immune systems. It has been demonstrated that $H$. alvei produces $\mathrm{N}$-acyl homoserines lactones (AHLs), the signaling molecules involved in the mechanism called quorum sensing (QS) (Gram et al., 1999; Ravn et al., 2001; Bruhn et al., 2004; Pinto et al., 2007). QS is used by many bacteria to coordinate community behavior as a function of population density (Fuqua et al., 1994; Whitehead et al., 2001). In some bacteria, quorum signaling is an essential regulatory component of virulence and other attributes, including biofilm formation (Nadell et al., 2008). The control of biofilms represents one of the most persistent challenges to industry in which these microbial communities are problematic (Kumar and Anand, 1998). Quorum quenching has been proposed as a new strategy to control a range 
of bacterial phenotypes, including biofilm formation, through interference with the communication system (Hentzer et al., 2002; Al-Bataineh et al., 2006).

Many organisms in marine environments protect their surfaces from microbial colonization by producing chemical defense compounds. The Australian marine red algae species Delisea pulchra protects itself against colonization by producing a wide spectrum of halogenated furanone compounds, some of which have interesting biological activities against phenotypes involved in the colonization pathways of marine bacteria (De Nys et al., 1995; Manefield et al., 2002). Furanones were found to interfere with QS, thereby inhibiting biofilm formation by Pseudomonas aeruginosa (Hentzer et al., 2002; Al-Bataineh et al., 2006).

Considering that QS and biofilm formation are often closely linked, this research aimed to detect the presence of signaling molecules in biofilm of $H$. alvei and evaluate the inhibitory effect of synthetic furanones on biofilm formation.

\section{METHODS}

\section{Bacteria strains and culture conditions}

Psychrotrophic $H$. alvei strains 059 and 071, isolated from cooled raw milk (Pinto, 2004), were used for biofilm studies in minimal media of salts - MMS $\left(\mathrm{K}_{2} \mathrm{HPO}_{4} 7\right.$ $\mathrm{g} \mathrm{l}^{-1} ; \mathrm{KH}_{2} \mathrm{PO}_{4} 2 \mathrm{~g} \mathrm{l}^{-1} ; \mathrm{MgSO}_{4} .7 \mathrm{H}_{2} \mathrm{O} 0.2 \mathrm{~g} \mathrm{l}^{-}$ 1; $\left(\mathrm{NH}_{4}\right)_{2} \mathrm{SO}_{4} 1 \mathrm{~g} \mathrm{l}^{-1}$; glycerol $4 \mathrm{~g} \mathrm{l}^{-1}$ and $\left.\mathrm{CaCl}_{2} 1 \mathrm{mmol} \mathrm{1}^{-1}\right)$. The strains were stored in brain heart infusion (BHI) with $40 \%$ (v/ v) glycerol and maintained at $-80^{\circ} \mathrm{C}$. Before each assay, they were grown in Luria Bertani broth (LB) (peptone $10 \mathrm{~g} \mathrm{l}^{-1}$, yeast extract $\left.5 \mathrm{~g} \mathrm{l}^{-1}, \mathrm{NaCl} 5 \mathrm{~g} \mathrm{l}^{-1}\right)$ at $26^{\circ} \mathrm{C}$ for 18 h. AHL production was detected using Chromobacterium violaceum CV026 (McClean et al., 1997), Escherichia coli pSB403 (Winson et al., 1998) and Agrobacterium tumefaciens WCF47 (Zhu et al., 2003) as monitor strains. C. violaceum and $E$. coli were grown in LB and, when appropriate, the broth was supplemented with $0.75 \%$ or $1.2 \%(\mathrm{w} / \mathrm{v})$ agar and antibiotics: $20 \mu \mathrm{g} \mathrm{ml} \mathrm{m}^{-1}$ kanamycin for $C$. violaceum $\mathrm{CV} 026$ and $20 \mu \mathrm{g} \mathrm{ml} \mathrm{m}^{-1}$ of tetracycline for $E$. coli pSB403. A. tumefaciens WCF47 was cultured in minimal AT media (Tempé et al., 1977) supplemented with $20 \mu \mathrm{g} \mathrm{ml}^{-1}$ of tetracycline and $100 \mu \mathrm{g} \mathrm{ml}^{-1}$ of kanamycin. These strains were incubated at $26^{\circ} \mathrm{C}$ for 24 $\mathrm{h}$, with shaking at $150 \mathrm{rpm}$, prior the assay. An AHL-lacking mutant of $H$. alvei 071 was constructed by Campos (2008) and was unable to induce violacein production after $24 \mathrm{~h}$ of incubation at $30^{\circ} \mathrm{C}$. This mutant was maintained on LB agar containing kanamicin $\left(50 \mu \mathrm{g} \mathrm{ml}^{-1}\right)$ and gentamicin (25 $\left.\mu \mathrm{g} \mathrm{ml} \mathrm{l}^{-1}\right)$.

Detection of AHLs in extracts of sessile and planktonic cells

Biofilms of $H$. alvei 059 and 071 were formed on 15 coupons $\left(2 \times 6 \times 0.1 \mathrm{~cm}^{2}\right)$ of stainless steel in MMS after $24 \mathrm{~h}$ of incubation at $26^{\circ} \mathrm{C}$, as suggested by Joseph et al. (2001). Coupons were removed from culture media, washed with $0.85 \%$ saline solution, immersed in $150 \mathrm{ml}$ saline and sonicated for $30 \mathrm{~min}$ (Ultrasonic Cleaners model 1510 water bath) to remove the added cells. Cell suspensions were centrifuged at $13,000 \mathrm{~g}$ for $30 \mathrm{~min}$ (RC5S, Dupont, USA) and AHLs in supernatants were extracted twice with equal volumes of ethyl acetate acidified with $0.5 \%$ of formic acid, according to Ravn et al. (2001). Extracts were filtered and evaporated to dryness in a rotative evaporator (MA 120, Marconi, Brazil). After complete evaporation, extracts were suspended in sterile distilled water. The same procedure was used to obtain extracts from cells in planktonic stages and from uninoculated MMS, as a negative control.

The presence of AHLs in extracts was verified by assaying violacein production by C. violaceum CV026, $\beta$-galactosidase induction by $A$. tumefaciens WCF47 or bioluminescence production by $E$. coli (pSB403). Bioluminescence produced by $E$. coli (pSB403) was monitored in a dark room, after $14 \mathrm{~h}$ of incubation and images were captured in Eagle Eye II (Stratagene, La Jolla, CA, USA). Twenty-five microliters 
of extract was dispensed in a $3 \mathrm{~mm}$ diameter well made in $1.2 \%$ LB agar, with the addition of appropriate antibiotics and previously inoculated with approximately $10^{7} \mathrm{CFU} \mathrm{ml}-1$ of $C$. violaceum $\mathrm{CV} 026$ or $E$. coli (pSB403). A. tumefaciens was inoculated in $1.2 \%$ AT agar with appropriate antibiotics.

Aliquots of $25 \mu$ of N-hexanoyl-D-Lhomoserine lactone (HHL), $75 \mathrm{nmol} \mathrm{l}^{-1}$ or $25 \mu$ of MMS extract were added to wells as positive and negative controls, respectively. Each bioassay was conducted at least twice in an independent manner.

\section{AHL characterization}

The AHLs contained in the sessile and planktonic cell extracts of $H$. alvei 059 and 071, obtained as described above, were also analyzed by reverse phase thin layer chromatography (TLC) adapted from Shaw et al. (1997). Cultures extract were dissolved in 400-600 $\mu \mathrm{l}$ of HPLC-grade ethyl acetate. Synthetic AHLs or extract samples dissolved in ethyl acetate, in volumes of 10-20 $\mu \mathrm{l}$, were spotted onto aluminum sheets (C18, RP, 254s, Merck, Germany) measuring 20 x $20 \mathrm{~cm}$. The standards used were: $\alpha$-amino- $\gamma-$ butyrolactone hydrobromide, N-hexanoylDL-homoserine lactone, N-decanoyl-DLhomoserine lactone, N-dodecanoyl-DLhomoserine lactone and N-tetradecanoylDL-homoserine lactone (Fluka, Switzerland). The chromatography was run using a solvent system of methanol: water (60:40, v/v) and, after running, the solvent was evaporated. The dried plates were overlaid with $30 \mu \mathrm{l}$ of an overnight culture of A. tumefaciens WCF47. The spots were visualized after overnight incubation at $30^{\circ} \mathrm{C}$, according to the monitor strain used and retention factor $(\mathrm{R} f)$ values were calculated.

\section{Detection of AHLs in biofilms}

Biofilms of $H$. alvei 059 and 071 formed on stainless steel after $24 \mathrm{~h}$ of incubation were washed in sterilized $0.85 \%$ saline solution to remove non-attached cells. Each side of the coupons was then exposed to UV light
(312 $\mathrm{nm}, 52 \mathrm{~cm}$ of distance) for $30 \mathrm{~min}$ in order to inactivate most of the cells. The presence of AHLs in situ was determined by covering coupons with LB or AT agar supplemented with appropriate antibiotics

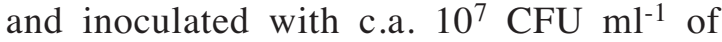
each monitor strain. The AT agar was also supplemented with $50 \mu \mathrm{g} \mathrm{ml} \mathrm{m}^{-1}$ of $\mathrm{X}$-gal. Petri dishes were incubated at $30^{\circ} \mathrm{C}$ and results were observed up to $24 \mathrm{~h}$. It was previously verified that a few viable cells remained in coupons treated with UV, but no changes in the turbidity of the LB medium was observed within $24 \mathrm{~h}$ incubation of coupons immersed in it. This observation discarded the production of considerable quantities of AHLs during incubation of the coupons and monitor strains. Each bioassay was conducted at least twice in two independent experiments.

\section{Effect of furanones in biofilm formation}

In order to analyze the relationship between AHL production and biofilm formation in $H$. alvei, we study the effects of synthetic furanones, known Quorum Sensing Inhibitors (QSI)-molecules, on growth and biofilm formation by using the 96-well assay adapted from O'Toole and Kolter (1998). The H. alvei 071 strain was cultured overnight at $26^{\circ} \mathrm{C}$, under shaking. Eighteen microliters of $H$. alvei cultures, with

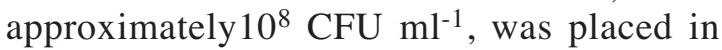
each well containing $180 \mu \mathrm{l}$ of MMS media added with synthetic furanones (Fluka Laboratory Chemicals, Milwaukee, Wis., USA). The furanones used were 3-methyl$2(5 \mathrm{H})$ furanone $(\mathrm{MF}), 2$-methyltetrahydro3-furanone (MTHF), 2(5H)-furanone (F) and 2,2-dimethyl-3(2H) furanone (DMTHF), at the final concentration of $0.01,0.1$ and $1 \mathrm{~mol} \mathrm{l}^{-1}$. The microplates were incubated at $26^{\circ} \mathrm{C}$ for $24 \mathrm{~h}$ and the cell growth determinate at $600 \mathrm{~nm}$. The planktonic cells were removed and the remaining adherent cells were stained for $30 \mathrm{~min}$ with $200 \mu \mathrm{l}$ of $0.1 \%(\mathrm{w} / \mathrm{v})$ crystal violet solution dispensed in each well. Excess stain was removed by washing three times with distilled water and $200 \mu \mathrm{l}$ of $95 \%(\mathrm{v} / \mathrm{v})$ ethanol was added to the wells to release the stain. The extent of biofilm 
development was determined by measuring the absorbance of the resulting solution at $600 \mathrm{~nm}$. For each experiment, correction for background staining was made by subtracting the value for crystal violet bound to uninoculated controls. The biofilm assay was performed twice, with triplicates in each assay. The data were expressed as the ratio between the optical density relative to the sessile and total cells and were submitted to variance analysis. When it was significant, the Dunnet test at $5 \%$ of probability was employed using the Windows 2006 version of the Genes program (Cruz, 2006).

\section{Biofilm observation by scanning electron microscopy}

Confirmation of the presence of biofilm on polystyrene was obtained by scanning electron microscopy. Two hundred microliters of high DO $600 \mathrm{~nm}$ activated cells of $H$. alvei 071 and $H$. alvei 071 halI mutant were inoculated in 24 wells on polystyrene microplates containing MMS, with $1 \mathrm{~mol}^{-1}$ of $2(5 \mathrm{H})$-furanone added, obtaining a final volume of $2 \mathrm{ml}$. As controls, MMS was used with a suspension of cells added and MMS without any addition. Polystyrene coupons measuring 1 $\mathrm{x} 1.2 \mathrm{~cm}$ were immersed in the wells and microplates were incubated for $48 \mathrm{~h}$. Coupons of each treatment were removed and submitted to appropriate treatments before being observed in a scanning electron microscope $\left(\mathrm{Leo}^{\circledR}\right.$, model VP 1430).

\section{RESULTS}

\section{AHLs in extract of sessile and planktonic cells}

Extracts obtained from planktonic cells of H. alvei 059 and 071 cultured in MMS induced violacein production by $C$. violaceum $\mathrm{CV} 026$, $\beta$-gal production by $\mathrm{A}$. tumefaciens WCF47 and bioluminescence by $E$. coli pSB403. However, extract from sessile cells of both strains did not activate a quorum-sensing response in $C$. violaceum
CV026. The results obtained with $H$. alvei 071 were presented to illustrate the detection of AHLs in extract of sessile and planktonic cells (Fig. 1).

\section{AHLs characterization}

In agreement with the results obtained with the different reporter strains, TLC experiments allowed us to characterize the homoserine lactones molecules produced by the strains in the sessile and planktonic stages (Fig. 2). Comparing the $\mathrm{R} f$ values of spots from samples with standard spots, it can be inferred that $H$. alvei produced AHLs with carbon chains similar to HHL, whose acyl chain might be substituted or not at the third carbon atom. However, spots corresponding to HHL were not detected in extract of planktonic cells of strain 059 (Fig. 2). The production of molecules with carbon chains composed of less than six carbon atoms was also demonstrated. Although the forms of spots obtained were different, the oxo and hydroxy derivatives, with the same chain length, migrate with no distinguishable mobility in the solvent system.

\section{AHLs production in biofilms}

H. alvei strains produced AHLs in biofilm formed on stainless steel and these molecules were detected by at least one monitor strain, with A. tumefaciens WCF47 being the most sensitive to AHL (Table 1).

\section{Effect of furanones in biofilm formation}

Furanones added to MMS broth up to $1 \mathrm{~mol}$ $1^{-1}$ did not affect $\mathrm{OD}_{600 \mathrm{~nm}}(P>0.05)$ relative to growth and biofilm formation of $H$. alvei 071. However, when the ratio between the optical density relative to the sessile and total cells was calculated, a significant reduction $(P<0.05)$ in biofilm formation was determined in the presence of $\mathrm{MF}$, MTHF and F in concentration higher than $0.01 \mathrm{~mol} \mathrm{l}^{-1}$ when compared to control (Fig. 3). In our experimental conditions, furanone DMTHF did not cause a significant effect $(\mathrm{P}>0.05)$ on biofilm formation by $H$. alvei 071 (Fig. 3). 
Biofilm observation by scanning electron microscopy

The wild type of $H$. alvei 071 formed a densely packed biofilm (Fig. 4A), whereas the halI mutant appeared to grow rather as discontinuous sheets on the polystyrene surface (Fig. 4B). The addition of 2(5H)furanone $(\mathrm{F})$ to the culture media reduced the cell number of $H$. alvei 071 adhering to coupons and after $48 \mathrm{~h}$ of incubation, isolated cells predominated.
DISCUSSION

There is clear evidence that biofilm formation is a carefully orchestrated process that is dependent on quorum sensing and that AHLs affect several aspects of biofilm dynamics in gramnegative bacteria, such as heterogeneity, architecture, stress resistance, maintenance and sloughing (Davies et al., 1998; Allison et al., 1998; Kjelleberg and Moli; 2002). Our results demonstrate the presence of

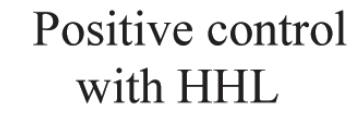

A

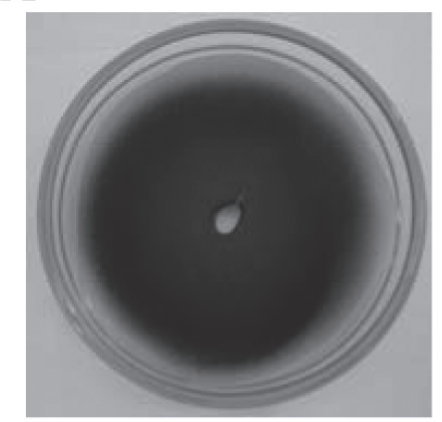

D
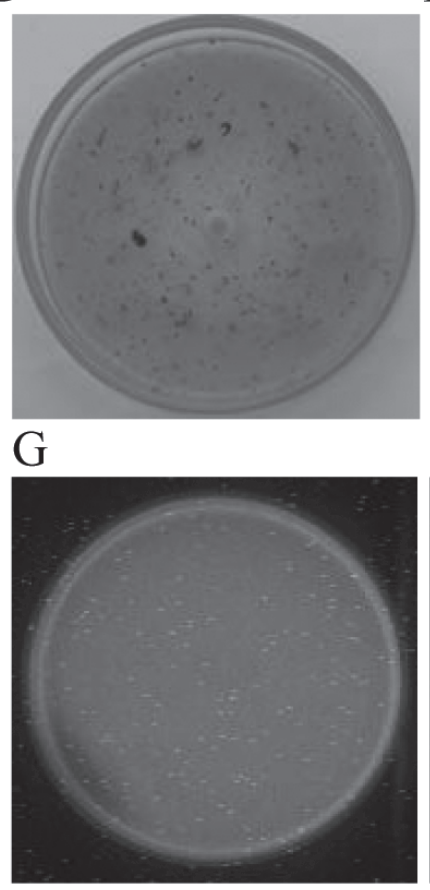

Extract of

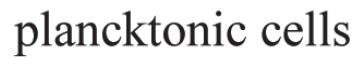

B

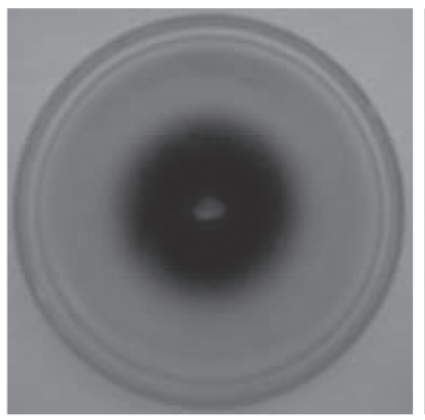

E
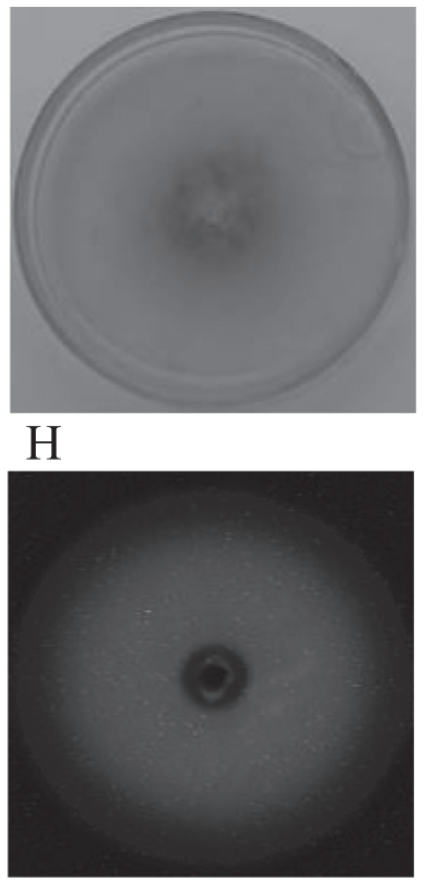

Extract of sessile cells

C

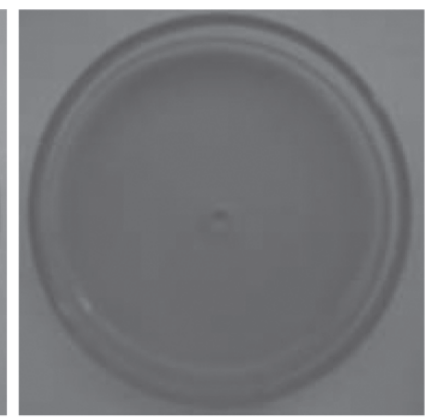

F

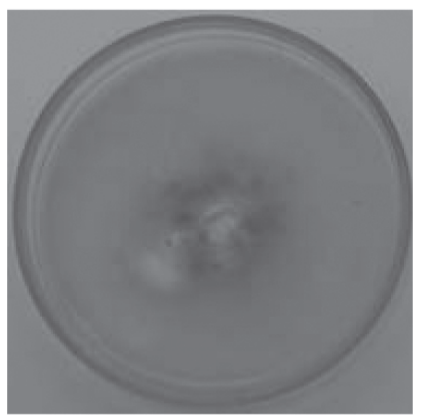

I

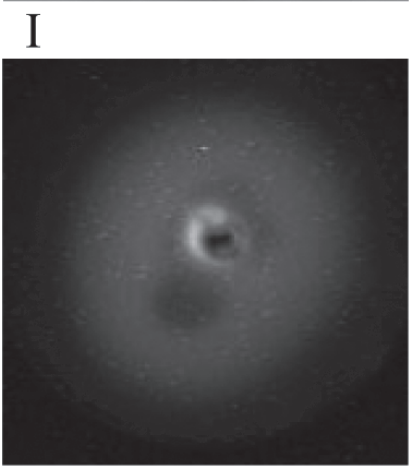

Fig. 1: Detection of AHLs produced by planktonic and sessile cells of H. alvei 071 using the monitor strains C. violaceum CV026 (A-C); A.tumefaciens WCF47 (D-F) and E. coli pSB403 (G-I). 


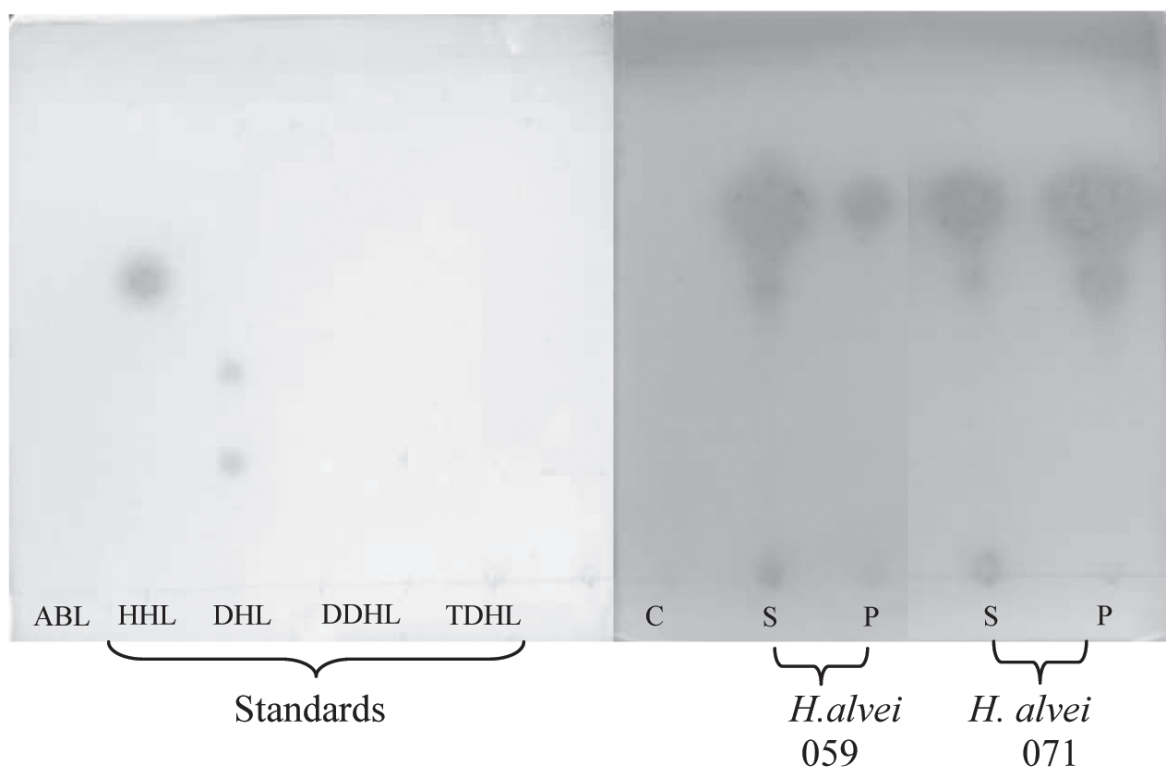

Fig. 2: Thin layer chromatography of extracts of AHLs obtained of sessile (S) and planktonic (P) cells of $H$. alvei 059 and 071 cultured in MMS for $24 \mathrm{~h}$, revealed with A. tumefaciens WCF47 reporter strain. Standards: $\alpha$-amino- $\gamma$-butyrolactone hydrobromyde (ABL); N-hexanoyl-DLhomoserine lactone (HHL); N-decanoil-DL-homoserine lactone (DHL); N-dodecanoyl-DLhomoserine lactone (DDHL); N-tetradecanoyl-DL-homoserine lactone (TDHL); C negative control from abiotic MMS medium.

\section{TABLE I}

Evaluation of AHL production in biofilm formed by $H$. alvei in coupons of stainless steel immersed in MMS and incubated at $26^{\circ} \mathrm{C}$, during $24 \mathrm{~h}$ using monitor strains.

\begin{tabular}{lccc}
\hline Strains & C. violaceum CV026 & A.tumefaciens WCF47 & E. coli pSB403 \\
\hline H. alvei 059 & - & ++ & - \\
H. alvei 071 & - & ++ & ++ \\
\hline
\end{tabular}

Signal intensity: (-) absent, (+) low, (++) medium.

AHLs in sessile cells of $H$. alvei on stainless steel determined by using culture techniques (Fig. 1) and by TLC (Fig. 2). This is strong evidence that QS also has a role in regulating biofilm formation in the evaluated strains. This kind of signal molecules has also been reported in biofilms formed by other bacteria, such as Nitrosomonas europea (Batchelor et al., 1997); P. fluorescens B52 (Allison et al., 1998); P. aeruginosa (Davies et al., 1998); Serratia marcescens (Rice and Koh, 2005); Burkholderia cepacia (Gotschilich et al., 2001; Huber et al., 2001; Conway et al.,
2002) and Aeromonas hydrophila (Lynch et al., 2002).

Although AHL production by $H$. alvei has already been reported (Gram et al., 1999; Bruhn et al., 2004; Pinto et al., 2007) this is the first time that AHL molecules were characterized in biofilms produced by this bacterium. This finding could help to better understand the adherence properties of $H$. alvei. Because $H$. alvei formed biofilms in stainless steel, it has the potential to colonize food-processing surfaces, and to be a continuous source of contamination when cells get detached from 


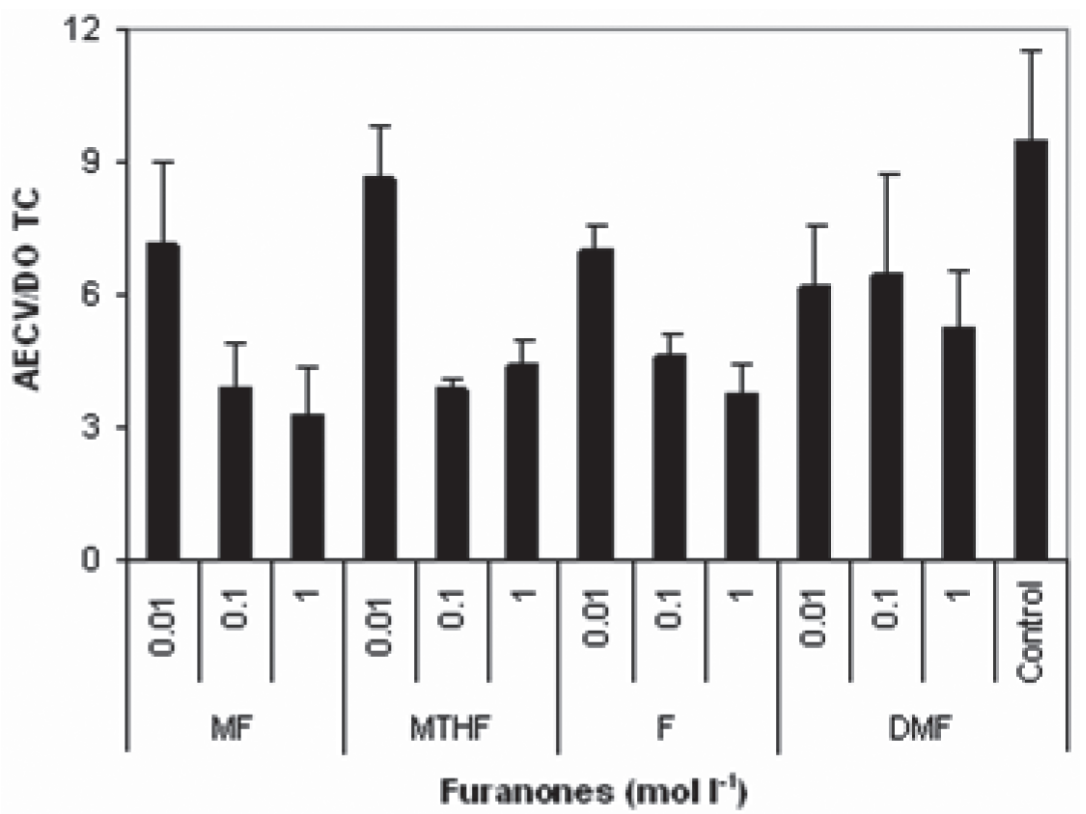

Fig. 3: Ratio between the absorbance of violet crystal (AECV) and optic density of total cells of $H$. alvei 071 in MMS after $24 \mathrm{~h}$ of incubation. MMS was added of: 3-metyl-2(5H)-furanone (DOTC) $(\mathrm{MF})$; metyltetrahydrofuranone (MTHF); 2(5H)-furanone (F); 2,2-dimetyl-3(2H)-furanone (DMF) in concentrations of $0.01 ; 0.1$ and $1 \mathrm{~mol} \mathrm{l}^{-1}$.

the biofilm and come in contact with food products.

Cells of H. alvei 059 and 071 attached in biofilm did not induce violacein production by $C$. violaceum CV026, but induced responses in $A$. tumefaciens or $E$. coli (Table 1). This result confirmed the importance of using diverse monitoring systems to detect AHLs. It should be emphasized that a negative response in this assay shows an inability to produce AHLs that are recognizable to $C$. violaceum CV026 or that the number of AHLs is very low or zero. Every monitoring system presents different degree of sensitivity and responds to specific groups of AHL (Zhu et al., 2003). For example, C. violaceum CV026 does not detect AHL with hydroxy substitution in the acylated chain and lacks sensitivity to many oxo derivatives (McClean et al., 1997; Cha et al., 1998).

The observation that the addition of furanone to culture media affected biofilm formation by $H$. alvei 071 (Fig. 3) can be attributed to inhibition of the QS system of this bacterium. Furanones can bind to the LuxR protein, thereby reducing the amount of protein available to interact with AHL or promoting the degradation of this protein, thus impeding the transcription of genes involved in regulation of biofilm formation (Manefield et al., 1999; Rasmussen et al., 2000; Hentzer et al., 2002). The inhibition of the expression of phenotypes controlled by QS by furanones was already recognized in a range of bacteria. Givskov et al. (1996) demonstrated that swarming migration of pathogenic bacteria Serratia liquefaciens on agar surface was completely inhibited by the addition of $100 \mathrm{mg} \mathrm{l}^{-1}$ of (5Z)-4-brome5 - (bromomethylene)-3-butyl-2(5H)furanone. This molecule also suppressed the expression of luminescence genes, localized in a reporter plasmid in $S$. liquefaciens, without affecting bacterial growth rate. Furanones also inhibits virulence genes, as seen by the production of extracellular toxin in the pathogenic strain of Vibrio harveyi (Manefield et al., 2000).

A mutation that blocks generation of the signal molecule hinders abnormal biofilm formation by $H$. alvei 071 , whereas the presence of $1 \mathrm{~mol}^{-1}$ of $2(5 \mathrm{H})$-furanone inhibited the biofilm formation (Fig. 4). 
These results suggested that a cell-to-cell signal is required for the differentiation of individual cells of $H$. alvei 071 into complex multicellular structures. Inhibition of biofilm formation was verified in $P$. aeruginosa using furanone 56 and this substance did not influence the initial adhesion process, but affected the biofilm architecture and increased the detachment process, leading to loss of biomass from the substrate (Hentzer et al., 2002). These authors also observed that this substance reduced the expression of virulence genes, indicating a general effect of furanone 56 on target genes of las circuit of QS in $P$. aeruginosa. The precise role of AHLs in biofilms remains to be established and more studies should be conducted to elucidate the involvement of QS in the different stages of biofilm formation by these bacteria.

A

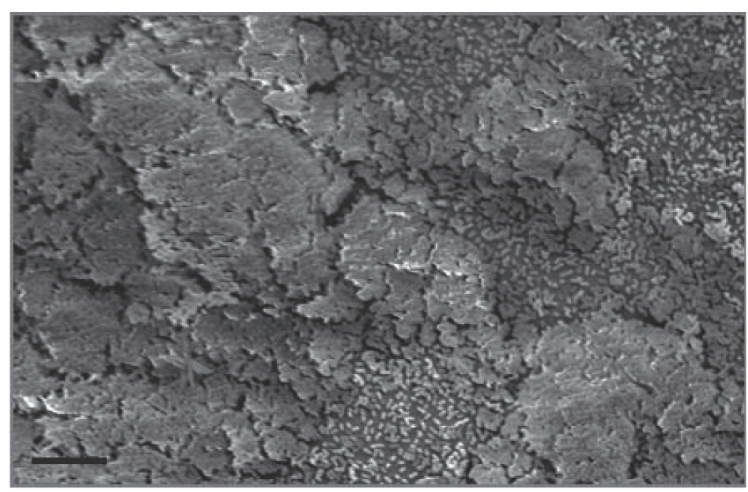

B

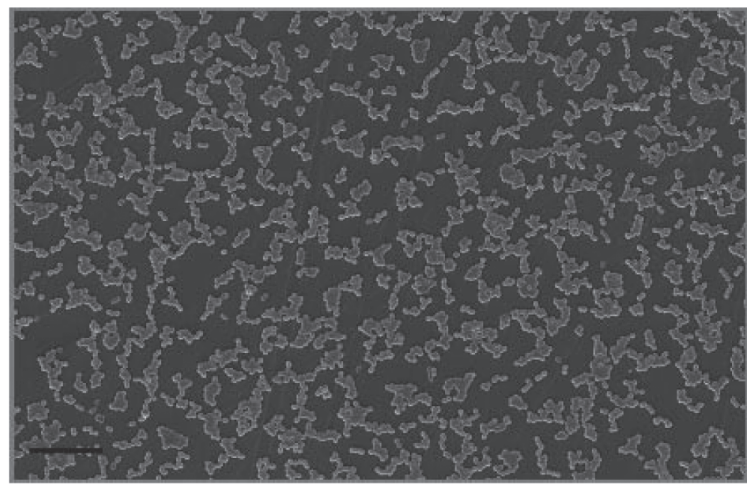

C

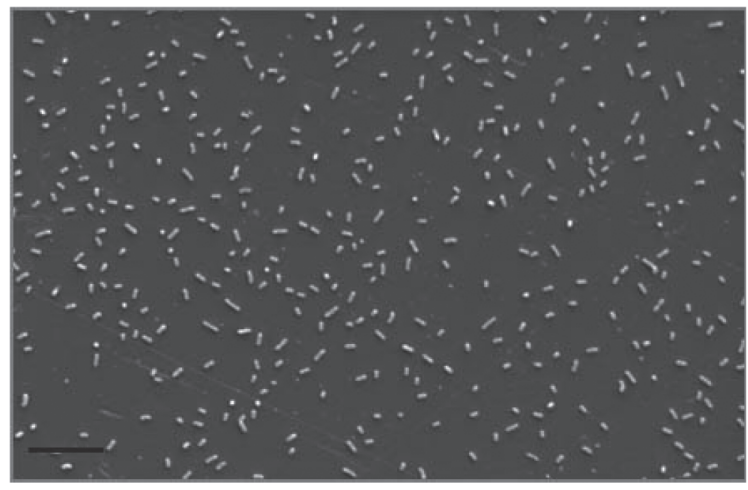

Fig. 4: Photomicrography of biofilm formed by $H$. alvei 071 wild type and hall mutant in coupons of polystyrene immersed in MMS. After $48 \mathrm{~h}$ of incubation, images were obtained by scanning electron microscopy. (A) H. alvei 071; (B) H. alvei 071 hall mutant (C) H. alvei 071 in presence of $1 \mathrm{~mol} \mathrm{l}^{-1}$ of 2(5H) furanone. Magnification x 2500, bar indicates $10 \mathrm{~mm}$. 


\section{ACKNOWLEDGEMENTS}

E.S. Viana was supported by CAPES-Brazil fellowship. The authors are grateful to Cláudia Alencar Vanetti for her assistance with the electronic microscopy.

\section{REFERENCES}

AL-BATAINEH SA, BRITCHER LG, GRIESSE HJ XPS (2006) Characterization of the surface immobilization of antibacterial furanones. Surface Sci 600: 952-962

ALLISON DG, RUIZ B, SANJOSE C, JASPE, A (1998) Extracellular products as mediators of the formation and detachment of Pseudomonas fluorescens biofilms. FEMS Microbiol Lett 167: 179-184

BATCHELOR SE, COOPER M, CAHHABRA SR, GLOVER LA, STEWART GSB, WILLIAMS P, PROSSER JJ (1997) Cell-density regulated recovery of starved biofilm populations of ammonia-oxidizing bacteria. Appl Environ Microbiol 63: 2261-2266

BRUHN JB, CHRISTENSEN AB, FLODGAARD LR, NIELSEN KF, LARSEN T, GIVSKOV M, GRAM L (2004) Presence of acylated homoserine lactones (AHLs) and AHL-producing bacteria in meat and potential role of AHL in spoilage of meat. Appl Environ Microbiol 70: 4293-4302

CAMPOS MEM (2008) Obtenção de mutantes de bactérias psicrotróficas isoladas de leite deficientes na produção de molécula sinal de quorum sensing. 43p. (MS em Microbiologia Agrícola) - Departamento de Microbiologia, Universidade Federal de Viçosa

CHA C, GAO P, CHEN Y-C, SHAW PD, FARRAND SK (1998) Production of acyl-homoserine lactone quorumsensing by Gram-negative plant-associated bacteria. Mol Plant-Microbe Interact 11: 1119-1129

CONWAY BAD, VENU V, SPEERT DP (2002) Biofilm formation and acyl homoserine lactone production in the Burkholderia cepacia complex. J Bacteriol 184: $5678-5685$

CRUZ CD (2006) Programa Genes: estatística experimental e matrizes. Viçosa: Editora UFV, 285 p

DAVIES DG, PARSEK MR, PEARSON JP, IGLEWSKI BH, COSTERNON JW, GREENBERG EP (1998) The involvement of cell-to-cell signals in the development of a bacterial biofilm. Sci 280: 295-298

DE NYS R, STEINBERG P, WILLEMSEM P, DWORJANYN S, GABELISH C, KING R (1995) Broad spectrum effects of secondary metabolites from the red alga Delisea pulchra in antifouling. Biofoul 8: 259-271

DESMASURES N (1995) Etude de laits de haute qualite: caracterisation et aptitudes microbiologiques a la transformation en camembert au lait cru. P.h. D. Thesis. Institute Biochemistry and Applied Biology, University of Caen, Caen, France

FUQUA WC, WINANS SC, GREENBERG EP (1994) Quorum sensing in bacteria: the LuxR/LuxI family of cell density-responsive transcriptional regulators. J Bacteriol 176: 269-275

GIVSKOV M, NYS R, MANEFIELD M, GRAM L, MAXIMILIEN LE, MOLIN S, STEINBERGPD, KJELLEBERG S (1996) Eukaryotic interference with homoserine lactone-mediated prokaryotic signaling. J Bacteriol 178: 6618-6622

GOTSCHILICH A, HUBER B, GEISWENBERGER O,
TOGI A, STEIDLE A, RIEDEL K, HILL P, TUMMLER B, VANDAMME P, MIDDLETON B, CAMARA M, WILLIAMS P, HARDMAN A, EBERL L (2001) Synthesis of multiple N-acylhomoserine lactones is widespread among the members of the Burkholderia cepacia complex. System Appl Microbiol 24: 1-14

GRAM L, CHRISTENSEM AB, RAVN L, MOLIN S (1999) Production of acylated homoserine lactones by psychrotrophic members of Enterobacteriaceae isolated from foods. Appl Environ Microbiol 65: 34583463

HENTZER M, RIEDEL K, RASMUSSEN TB, HEYDORN A, ANDERSEN JB, PARSEK MR, RICE SA, EBERL L, MOLIN S, HOIBY N, KJELLEBERGS, GIVSKOV $M$ (2002) Inhibition of quorum sensing in Pseudomonas aeruginosa biofilm bacteria by a halogenated furanone compound. Microbiol 148: 87102

HUBER B, RIEDEL K, HENTZER M, HEYDORN A, GOTSCHILICH M, GIVSKOV M, MOLIN S, EBERL L (2001) The cep quorum-sensing system of Burkholderia cepacia $\mathrm{H} 111$ controls biofilm formation and swarming motility. Microbiol 147: 2517-2528

JACK RF, RINGELBERG DB, WHITE DC (1992) Differential corrosion rates of carbon steel by combinations of Bacillus sp., Hafnia alvei and Desulfovibrio gigas established by phospholipid analysis of electrode biofilm. Corrosion Sci 33: 18431853

JOSEPH B, OTTA SK, KARUNASAGAR I, KARUNASAGAR, I. (2001) Biofilm formation by Salmonella spp. on food contact surfaces and their sensitivity to sanitizers. Int J Food Microbiol 64: 367372

KAGKLI DM, VANCANNEYT M, VANDAMME P, HILL C, COGAN TM (2007) Contamination of milk by enterococci and coliforms from bovine faeces. J Appl Microbiol 103: 1393-1405

KATZENELLENBOGEN E, ZATONSKY V, KOCHAROVA NA, ROWINSKI S, GAMIAN A, SHASHKOV S, ROMANOWSKA E (2001) Structure of the O-specific polysaccharide of Hafnia alvei PCM 1196. Carbohydrate Res 30: 523-528

KUMAR CG, ANAND SK (1998) Significance of microbial biofilms in food industry: a review. Int $\mathrm{J}$ Food Microbiol 42: 9-27

LINDBERG AM, LJUNGH A, AHRNEnS, LOFDAHL S, MOLIN G (1998) Enterobacteriaceae found in high numbers in fish, minced meat and pasteurised milk or cream and the presence of toxin encoding genes. Int $\mathrm{J}$ Food Microbiol 39: 11-17

LYNCH MJ, SWIFT S, KIRKE DF, KEEVIT W, DODD CER, WILLIAMS P (2002) The regulation of biofilm development by quorum sensing in Aeromonas hydrophila. Environ Microbiol 4: 18-28

McCLEAN KH, WINSON MK, FISH L, TAYLOR A, CAHABRA SR, CAMARA M, DAYKIN M, LAMB JH, SWIFT S, BYCROFT BW, STEWART GS, WILLIAMS P (1997) Quorum sensing and Chromobacterium violaceum: exploitation of violacein production and inhibition for the detection of $\mathrm{N}$ acylhomoserine lactones. Microbiol 143: 3703-3711

MANEFIELD M, DE NYS R, KUMAR N, READ R, GIVSKOV $M$, STEINEBERG P, KJELLEBERG S (1999) Evidence that halogenated furanones from Delisea pulchra inhibit acylated homoserine lactone (AHL) mediated gene expression by displacing the AHL signal from its receptor protein. Microbiol 145: 283-291 
MANEFIELD M, HARRIS L, RICE SA, DE NYS R, KJELLEBER GS (2000) Inhibition of luminescence and virulence in the black tiger prawn (Penaeus monodon) pathogen Vibrio harveyi by intercellular signal antagonists. Appl Environ Microbiol 66: 20792084

MANEFIELD M, RASMUSSEN TB, HENZTER JB, ANDERSEN P, STEINBERGS, KJELLEBER GS, GIVSKOV M (2002) Halogenated furanones inhibit quorum sensing through accelerated LuxR turnover. Microbiol 148: 1119-1127

NADELL CD, XAVIER JB, LEVIN SA, FOSTER KR (2008) The evolution of quorum sensing in bacterial biofilms. PLOS Biol 6: 171-179

O'TOOLE GA, KOLTER R (1998) The initiation of biofilm formation in Pseudomonas fluorescens WSC365 proceeds via multiple, convergent signaling pathways: a genetic analysis. Mol Microbiol 28: 449461

PINTO CLO (2004) Bactérias psicrotróficas proteolíticas do leite cru refrigerado granelizado destinado à produção de leite UHT. 97p. Tese (Doutorado em Microbiologia Agrícola) - Departamento de Microbiologia, Universidade Federal de Viçosa

PINTO UM, VIANA ES, MARTINS ML, VANETTI MCD (2007) Detection of acylated homoserine lactones in gram-negative proteolytic psychrotrophic bacteria isolated from cooled raw milk. Food Cont 18: 13221327

RASMUSSEN TB, MANEFIELD M, ANDERSEN JB, EBERL L, ANTHONY U, CHRISTOPHERSEN C, STEINBERG P, KJELLEBERG S, GIVSKOV M (2000) How Delisea pulchra furanones affect quorum sensing and swarming motility in Serratia liquefaciens MG1. Microbiol 146: 3337-3244

RAVN L, CHRISTENSEN AB, MOLIN S, GIVSKOV M, GRAM L (2001). Methods for detecting acylated homoserine lactones produced by Gram-negative bacteria and their application in studies of AHLproduction kinetics. J Microbiol Meth 44: 239-251
RICE SA, KOH KS (2005) Biofilm formation and sloughing in Serratia marcescens are controlled by quorum sensing and nutrient cues. J Bacteriol 187: 3477-3485

SHAW PD, PING G, DALY SL, CHUNG C, CRONAN JE, RINEHART KL, FARRAND SK (1997) Detection and characterizing $\mathrm{N}$-acil-homoserine lactone signal molecules by thin-layer chromatography. Proc Nat Acad Sci USA 94: 6036-6041

SAKAZAKI R, TAMURA K (1992) The genus Hafnia. In: BALLOWS, A, TRÜPER HG, DWORKIN M, HARDER W, SCHEIFER KH (eds). The Prokaryotes, a handbook on the biology of the bacteria: ecophisyology, isolation, identification, applications. Berlin: Springer-Verlag, pp 2816-2821

TEMPÉ J, PETIT A, HOLSTERS M, VAN MONTAGU M, SCHELL J (1977) Thermosensitive step associated with transfer of Ti plasmid during conjugation: possible relation to transformation in crown gall. Proc Nat Acad Sci USA 74: 2848-2849

VIVAS J, PADILLA D, REAL F, BRAVO J, GRASSO V, ACOSTA F (2008). Influence of environmental conditions on biofilm formation by Hafnia alvei strains. Vet Microbiol 129: 150-155

WHITEHEAD NA, BARNARD AML, SLATER H, SIMPSON NJL, SALMOND GPC (2001) Quorumsensing in Gram-negative bacteria. FEMS Microbiol Rev 25: 365-404

WINSON MK, SWIFT S, FISH L, THROUP JP, JØRGENSEN F, CHHABRA SR., BYCROFT BW, WILLIAMS P, STEWART GSAB (1998) Construction and analysis of luxCDABE-based plasmid sensors for investigating $N$-acyl homoserine lactone-mediated quorum sensing. FEMS Microbiol Lett 163: 85-192

ZHU J, CHAI Y, ZHONG Z, LI S, WINANS SC (2003) Agrobacterium bioassay strain for ultrasensitive detection of n-acylhomoserine lactone-type quorumsensing molecules: detection of autoinducers in Mesorhizobium huakuii. Appl Environ Microbiol 69: 6949-6953 